\title{
Prevention of Oxidative Injury in PC12 Cells by a Traditional Chinese Medicine, Shengmai San, as a Model of an Antioxidant-Based Composite Formula
}

\author{
Lei Wang, ${ }^{b}$ Hiroshi Nishida, ${ }^{a}$ Yoshihiro Ogawa, ${ }^{a}$ and Tetsuya Konishi ${ }^{*, a}$ \\ ${ }^{a}$ Niigata University of Pharmacy and Applied Life Sciences; Niigata 950-2081 Japan: and ${ }^{b}$ College of Traditional \\ Chinese Medicine \& Pharmacology, Capital University of Medical Sciences; Beijing, 100013 China. \\ Received January 22, 2003; accepted April 4, 2003
}

\begin{abstract}
The protective effect of Shengmai San (SMS) on oxidative damage in cultured PC12 cells was studied as a model of an antioxidant-based composite formula usable for the treatment of oxidative stress-related complex disorders. SMS, a traditional Chinese herbal medicine, has previously been shown to prevent cerebral oxidative injury in rats. Neuronal model PC12 cells were incubated with SMS for defined periods, chased with $\mathrm{H}_{2} \mathrm{O}_{2}$ for $30 \mathrm{~min}$ at $37^{\circ} \mathrm{C}$, and subjected to an ELISA-based assay for determining the protein carbonyl content, and a Comet assay for DNA single strand breaks (SSBs). The results showed that both protein carbonyl content and DNA SSBs increased in $\mathrm{PC1} 2$ cells after the $\mathrm{H}_{2} \mathrm{O}_{2}$ chase in a concentration-dependent manner. Both $\mathrm{H}_{2} \mathrm{O}_{2}$-dependent carbonyl formation and DNA damage were markedly prevented in the cells pretreated with SMS, and the SMS effects were dependent on both the SMS concentration and the period of pre-incubation with SMS before the $\mathrm{H}_{2} \mathrm{O}_{2}$ abuse. At the same time, cell viability was enhanced in the SMS-pretreated cells after the $\mathrm{H}_{2} \mathrm{O}_{2}$ abuse compared to the control cells as determined by an 3-(4,5-dimethylthiazol-2-yl)-2,5-diphenyltetrazolium bromide (MTT) assay. It is concluded that SMS functions not only as a simple antioxidant but also as a modulator of cellular antioxidant defense.
\end{abstract}

Key words traditional Chinese medicine; Shengmai San; oxidative stress; protein carbonyl; DNA damage; PC12 cells

Numerous reports have suggested that oxidative stress (OS) is implicated in neurotoxic insults ${ }^{1,2)}$ as well as in agerelated neurodegenerative diseases such as Parkinson's disease (PD) ${ }^{3)}$ and Alzheimer's disease (AD). ${ }^{4)}$ These disorders are associated with an accumulation of oxidative damage to lipids, proteins and DNA, ${ }^{5)}$ and changes in the antioxidant defense systems ${ }^{6)}$ including superoxide dismutase (SOD), catalase and glutathione peroxidase (GPX). In order to prevent oxidative brain damage, therapeutic usage of antioxidants or reducing agents, ${ }^{6-8)}$ such as Vitamin E, Vitamin C and apomorphine, has been trialed. This approach, however, showed only limited therapeutic effectiveness because the pathogenesis of oxidative tissue injury involves multiple disturbances of cellular physiological processes such as the elevation of intracellular $\left.\mathrm{Ca}^{2+} .9,10\right)$ To overcome the limited advantages of the use of a single antioxidant, we proposed antioxidant-based composite therapy for the prevention and repair of the complex diseases that are related to oxidative stress, and have shown that the traditional Chinese medicine Shengmai San (SMS), as a model of an antioxidant-based composite formula, effectively prevented the oxidative brain injury caused by ischemia-reperfusion in rats. ${ }^{11,12)}$ SMS is a composite formula comprising three component herbs, Panax Ginseng, Ophiopogon Japonicus and Schisandra Chinensis. It has been extensively used for treating coronal heart diseases. ${ }^{13,14)}$ To further understand the mechanism of the protective action of SMS on cerebral oxidative damage, it is useful to examine the effects of SMS on oxidatively abused cultured cells. In the present study, we further investigated the protective effects of SMS against oxidative cellular damage induced by $\mathrm{H}_{2} \mathrm{O}_{2}$ in cultured $\mathrm{PC} 12$ cells as a neuronal cell model.

\section{MATERIALS AND METHODS}

Materials Dulbecco's modified Eagle's medium (DMEM) and fetal bovine serum (FBS) were purchased from Sigma Chemical Co. Ltd., U.S.A. Antibiotics and antimycotics were from Gibco BRL Co. Ltd., U.S.A. Cell culture dishes and microplates were obtained from Corning Co. Ltd., U.S.A. 3-(4,5-Dimethylthiazol-2-yl)-2,5-diphenyltetrazolium bromide (MTT) was from Dojindo Co. Ltd., Japan. Mouse monoclonal IgE against 2,4-dinitrophenylhydrazine (DNPH) was from Sigma Co. Ltd., U.S.A. Rat anti-mouse IgE conjugated to horseradish peroxidase (HRP) was from SBA Inc., U.S.A. 3,3',5,5'-tetramethylbenzidine (TMB) was from BioRad Laboratories, U.S.A. The Comet assay kit was from Trevigen Co. Ltd., USA. SMS was provided by Iskura Co. Ltd., Japan.

Cell Culture and $\mathrm{H}_{2} \mathrm{O}_{2}$ Treatment Rat pheochromocytoma-derived PC12 cells were grown and maintained in DMEM supplemented with 10\% FBS and penicillin/streptomycin $(60 \mathrm{U} / \mathrm{ml})$ in a humidified atmosphere of $5 \% \mathrm{CO}_{2}$ and $95 \%$ air at $37^{\circ} \mathrm{C}$. The cells $\left(5 \times 10^{4} / \mathrm{cm}^{2}\right)$ were pre-incubated with nerve growth factor $\beta$ (NGF $\beta, 50 \mathrm{ng} / \mathrm{ml}$ ) for $4 \mathrm{~d}$ to induce neuronal differentiation. The differentiated cells were treated with SMS for defined periods. After removing external SMS by washing with fresh medium, the cells were chased with $\mathrm{H}_{2} \mathrm{O}_{2}$ in serum-free DMEM for 30 min at $37^{\circ} \mathrm{C}$. The cells were harvested and subjected to an ELISA-based assay for protein carbonyl content, and the Comet assay for DNA damage measurement.

Measurement of Protein Carbonyl Formation Protein carbonyl contents were measured by an ELISA method. ${ }^{15}$ ) Oxidized bovine serum albumin (BSA) was used as the carbonyl standard, and prepared by $\mathrm{Cu}^{2+} / \mathrm{H}_{2} \mathrm{O}_{2}(500 \mu \mathrm{m} / 5 \mathrm{mM})$ oxidation of BSA. The carbonyl content of the oxidized BSA standard was determined by a previously reported colorimet- 
ric method. ${ }^{16)}$ Cells were homogenized and reacted with $10 \mathrm{~mm}$ DNPH in $2 \mathrm{~N} \mathrm{HCl}$ at room temperature for $1 \mathrm{~h}$. Proteins were precipitated with $7 \%$ trichloroacetic acid (TCA) and then the protein concentration was measured by the bicinchoninic acid (BCA) method using BSA as the standard. ${ }^{17)} \mathrm{A}$ standard curve for the ELISA was prepared for the oxidized BSA diluted with intact BSA at defined ratios (0$40 \%)$. Aliquots $(100 \mu \mathrm{l})$ of test samples and standards $(4 \mu \mathrm{g}$ protein) were placed into a 96-well immunoplate and incubated overnight at $4{ }^{\circ} \mathrm{C}$. The plate was then washed with PBS containing $0.1 \%$ Tween 20 (PBST) and incubated with blocking buffer (1\% BSA in PBST) for $2 \mathrm{~h}$ at room temperature. The samples were further incubated with the primary antibody (mouse anti-DNP IgE; SIGMA) for $4 \mathrm{~h}$, washed with PBST and then incubated with the secondary antibody (rat anti-mouse IgE IgG-HRP conjugate; SBA) for $1 \mathrm{~h}$. The peroxidase reaction was initiated by the addition of TMB (Bio$\mathrm{Rad}$ Lab.) and stopped by the addition of $0.18 \mathrm{M} \mathrm{H}_{2} \mathrm{SO}_{4}$. The absorbance was measured at $450 \mathrm{~nm}$ using a Bio-Rad model 550 microplate reader.

Single Cell Gel Electrophoresis Assay (Comet Assay) The Comet assay was performed essentially according to the protocol for the rapid detection of DNA damage by the Cometassay ${ }^{\mathrm{TM}}$ kit (Trevigen). The sample cell suspensions $\left(1 \times 10^{5} / \mathrm{ml}\right)$ were mixed with low melting agarose and then applied directly onto a CometSlide ${ }^{\mathrm{TM}}$. After the agarose was clotted at $4{ }^{\circ} \mathrm{C}$ for $10 \mathrm{~min}$, the slides were immersed in chilled lysis buffer containing $2.5 \mathrm{~m} \mathrm{NaCl}, 100 \mathrm{~mm}$ EDTA, $10 \mathrm{~mm}$ Tris base ( $\mathrm{pH} 10), 1 \%$ sodium lauryl sarcosinate, $1 \%$ Triton X-100 for $60 \mathrm{~min}$ at $4{ }^{\circ} \mathrm{C}$ in the dark. Following the lysis treatment, the slides were immersed in freshly prepared alkali solution $(300 \mathrm{~mm} \mathrm{NaOH}, 1 \mathrm{~mm}$ EDTA, $\mathrm{pH}>13)$ for $20 \mathrm{~min}$ at room temperature. After two washes in $1 \times \mathrm{TBE}$ buffer (Tris $100 \mathrm{~mm}$, boric acid $90 \mathrm{~mm}$, EDTA $1 \mathrm{~mm}$ ) for $5 \mathrm{~min}$, the slides were set on an electrophoresis apparatus. Electrophoresis was conducted in the same buffer for $10 \mathrm{~min}$ at room temperature in the constant voltage mode $(1 \mathrm{~V} / \mathrm{cm})$. Slides were immersed in ethanol for $5 \mathrm{~min}$ and then dried under atmospheric pressure. The dried slides were stained with SYBR Green ${ }^{\mathrm{TM}}(0.1 \mu \mathrm{g} / \mathrm{ml}$ in TE buffer $\mathrm{pH} 7.5 ; 50$ $\mu \mathrm{l} / \mathrm{slide})$. The DNA damage was visualized under a fluorescence microscope (OLYMPUS model BH 2-RFCA) equipped with a charge-coupled device (CCD) camera. At least 100 comets were randomly recorded. The DNA damage was classified into five grades ( 0 to 4 ) as reported elsewhere ${ }^{18,19)}$ according to the comet tail length. The overall damage score was calculated from the arbitrary number $(0,100,200,300$, 400 ) given to the cells in each damage grade ( 0 to 4 , respectively). ${ }^{18,19)}$ Thus the damage score was in arbitrary units.

Cell Viability Measurement by MTT Cell viability was assessed by a modified MTT assay as described elsewhere. ${ }^{20)}$ Briefly, the cells were incubated with MTT $(5 \mathrm{mg} / \mathrm{ml})$ in a 48 well microplate for $2 \mathrm{~h}$ at $37^{\circ} \mathrm{C}$. The reaction was stopped by the addition of a cell lysis buffer containing $50 \%(\mathrm{w} / \mathrm{v}) \mathrm{N}, \mathrm{N}$ dimethylformamide and $20 \%$ sodium dodecyl sulfate (SDS) (pH 4.8). The plate was maintained overnight at $37^{\circ} \mathrm{C}$ and then the absorbance at $570 \mathrm{~nm}$ was determined.

Statistical Analysis The data were analyzed by analysis of variance (ANOVA) with SPSS10.0 software. $p<0.05$ was considered statistically significant. The results are presented as the means \pm standard deviation of 3 independent experi- ments.

\section{RESULTS}

Protection against $\mathrm{H}_{2} \mathrm{O}_{2}$-Induced Protein Oxidative Damage by SMS The preventive effects of SMS on protein carbonyl formation in PC12 cells were examined by ELISA after $\mathrm{H}_{2} \mathrm{O}_{2}$ abuse. The protein carbonyl content in the cells increased significantly after $\mathrm{H}_{2} \mathrm{O}_{2}$ treatment for $30 \mathrm{~min}$, although the carbonyl formation was not strictly dependent on the $\mathrm{H}_{2} \mathrm{O}_{2}$ concentration $(0.1-1 \mathrm{~mm})$. The carbonyl content increased to approximately 2.2 -fold with $0.1 \mathrm{mM} \mathrm{H}_{2} \mathrm{O}_{2}$ and no further marked increases were observed with higher $\mathrm{H}_{2} \mathrm{O}_{2}$ concentrations. The $\mathrm{H}_{2} \mathrm{O}_{2}$-dependent carbonyl formation was significantly prevented in the cells pretreated with SMS for $24 \mathrm{~h}$ before the $\mathrm{H}_{2} \mathrm{O}_{2}$ abuse at all $\mathrm{H}_{2} \mathrm{O}_{2}$ concentrations (Fig. 1).

The dose-dependent effects of SMS were further examined. Cells treated with increasing concentrations of SMS in the range of 0.16 to $0.66 \mathrm{mg} / \mathrm{ml}$ for $24 \mathrm{~h}$ were abused by $0.5 \mathrm{mM} \mathrm{H}_{2} \mathrm{O}_{2}$ for $30 \mathrm{~min}$ at $37^{\circ} \mathrm{C}$, and then the $\mathrm{H}_{2} \mathrm{O}_{2}$-induced protein carbonyl formation was determined. SMS significantly prevented the protein carbonyl formation in a dose-dependent manner (Fig. 2A). The SMS effect was also depen-

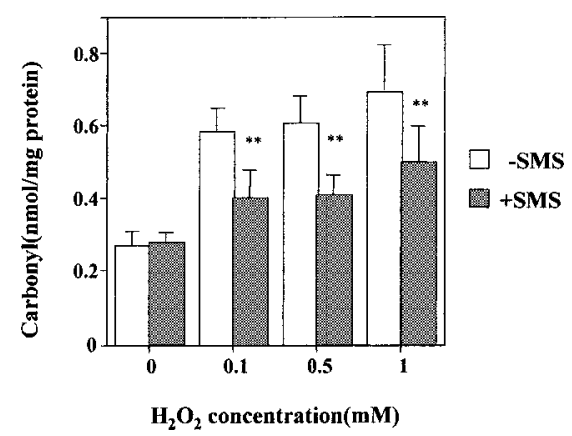

Fig. 1. Inhibition of $\mathrm{H}_{2} \mathrm{O}_{2}$-Dependent Carbonyl Formation in PC12 Cells by SMS

PC12 cells $\left(5 \times 10^{4} / \mathrm{cm}^{2}\right)$ were pre-incubated with or without SMS $(0.66 \mathrm{mg} / \mathrm{ml})$ for $24 \mathrm{~h}$ and then chased with various concentrations of $\mathrm{H}_{2} \mathrm{O}_{2}(0.1-1 \mathrm{mM})$ for $30 \mathrm{~min}$ at $37^{\circ} \mathrm{C}$. The cell culture conditions were described in the Materials and Methods. Protein carbonyl contents were determined by ELISA. Data represent the means \pm S.D. of 3 independent experiments. $* * p<0.01$ compared to the $\mathrm{H}_{2} \mathrm{O}_{2}$ controls.
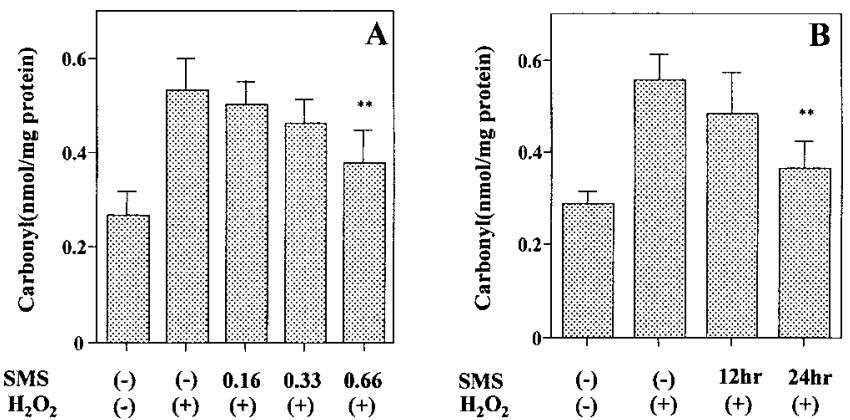

$\begin{array}{llllll}\text { SMS } & (-) & (-) & \mathbf{0 . 1 6} & \mathbf{0 . 3 3} & 0.66 \\ \mathrm{H}_{2} \mathrm{O}_{2} & (-) & (+) & (+) & (+) & (+)\end{array}$

$\begin{array}{lllll}\mathrm{H}_{2} \mathrm{O}_{2} & (-) & (+) & (+) & (+)\end{array}$

Fig. 2. Effects of SMS on $\mathrm{H}_{2} \mathrm{O}_{2}$-Dependent Carbonyl Formation in PC12 Cells

(A) PC12 cells were pre-incubated with various concentrations of SMS $(0.16$ $0.66 \mathrm{mg} / \mathrm{ml}$ ) for $24 \mathrm{~h}$ and then chased with $0.5 \mathrm{~mm} \mathrm{H}_{2} \mathrm{O}_{2}$ for $30 \mathrm{~min}$ at $37^{\circ} \mathrm{C}$. (B) Cells were pre-incubated with $0.66 \mathrm{mg} / \mathrm{ml}$ of SMS for defined periods $(12,24 \mathrm{~h})$ and then chased with $0.5 \mathrm{mM} \mathrm{H}_{2} \mathrm{O}_{2}$ for $30 \mathrm{~min}$. Protein carbonyl contents were determined by ELISA. The values represent the means \pm S.D. of 3 independent experiments. ** $p<0.01$ compared to the $\mathrm{H}_{2} \mathrm{O}_{2}$ control. 
dent on the preincubation time before the $\mathrm{H}_{2} \mathrm{O}_{2}$ treatment. The cells incubated for a longer period $(24 \mathrm{~h})$ showed stronger inhibitory potential against carbonyl formation than the cells incubated for a shorter period (12 h) (Fig. 2B).

Protection against $\mathrm{H}_{2} \mathrm{O}_{2}$-Induced DNA Damage by SMS The protective effect of SMS against $\mathrm{H}_{2} \mathrm{O}_{2}$-induced DNA damage was investigated in PC12 cells. First, the cells were treated with increasing concentrations of $\mathrm{H}_{2} \mathrm{O}_{2}(0.1-0.5 \mathrm{~mm})$ for $30 \mathrm{~min}$ at $37^{\circ} \mathrm{C}$ and then DNA single strand breaks (SSBs) were assessed by the Comet assay. More than 100 cells were randomly analyzed under a fluorescence microscope and the damage grade was classified into 5 groups (grade 0 to grade 4) according to the arbitrary criteria given for DNA damage (comet tail length) described elsewhere. ${ }^{18,19)}$ The cells with no comet tail but with a diffuse nucleus were classified into grade 1. The overall DNA damage, assessed as described in the Materials and Methods, with increasing concentrations of $\mathrm{H}_{2} \mathrm{O}_{2}$ showed that treatment of the cells with $0.5 \mathrm{~mm} \mathrm{H}_{2} \mathrm{O}_{2}$ resulted in serious DNA damage and the SSBs formation almost reached its highest level (378 \pm 7 arbitrary units). Since $0.3 \mathrm{mM} \mathrm{H}_{2} \mathrm{O}_{2}$ gave rise to significant damage (251 \pm 5 arbitrary units, cf. $35 \pm 4$ in untreated cells), the effect of SMS was examined in the cells treated with $0.3 \mathrm{~mm} \mathrm{H}_{2} \mathrm{O}_{2}$. The results showed that incubation with SMS for $24 \mathrm{~h}$ prior to the $\mathrm{H}_{2} \mathrm{O}_{2}$ chase effectively prevented the DNA damage and the effect was also dependent on the SMS concentration, as in the case for the carbonyl formation. The overall DNA damage was reduced to approximately $62 \%$ of the control with
$0.66 \mathrm{mg} / \mathrm{ml}$ of SMS (Fig. 3A). The protective effect of SMS was shown more clearly when the DNA damage grade histogram was precisely examined (Fig. 3B). The numbers of cells with grade 3 and grade 4 damage significantly decreased and instead the cells in grades 2 and 1 increased. Again, the SMS effect was also dependent on the period of preincubation before $\mathrm{H}_{2} \mathrm{O}_{2}$ abuse, and the longer incubation with SMS $(24 \mathrm{~h})$ gave rise to higher protection against the $\mathrm{H}_{2} \mathrm{O}_{2}$-induced DNA damage compared to the shorter incubation (12 h) (Fig. 4A, B).

Protection against $\mathrm{H}_{2} \mathrm{O}_{2}$-Induced Cell Death by SMS To investigate whether the SMS pretreatment is effective for preventing $\mathrm{H}_{2} \mathrm{O}_{2}$-induced cell death, the cell viability in PC12 cells pretreated with SMS after $\mathrm{H}_{2} \mathrm{O}_{2}$ abuse was further examined using the MTT assay. SMS significantly improved the cell viability in a dose-dependent manner $(76 \%$ by 0.33 and $83 \%$ by $0.66 \mathrm{mg} / \mathrm{ml} \mathrm{SMS}$, respectively) (Fig. 5A). The protective effect of SMS became more prominent when the cells were preincubated for longer periods with SMS. The cell viability was elevated from $77 \%$ in cells preincubated for $12 \mathrm{~h}$ to $81 \%$ in cells preincubated for $24 \mathrm{~h}$, as shown in Fig. $5 \mathrm{~B}$.

\section{DISCUSSION}

SMS is a traditional Chinese medicine (TCM) formula comprising three herbal components, and has been used for treating coronal heart diseases. ${ }^{13,14)}$ We focused our attention
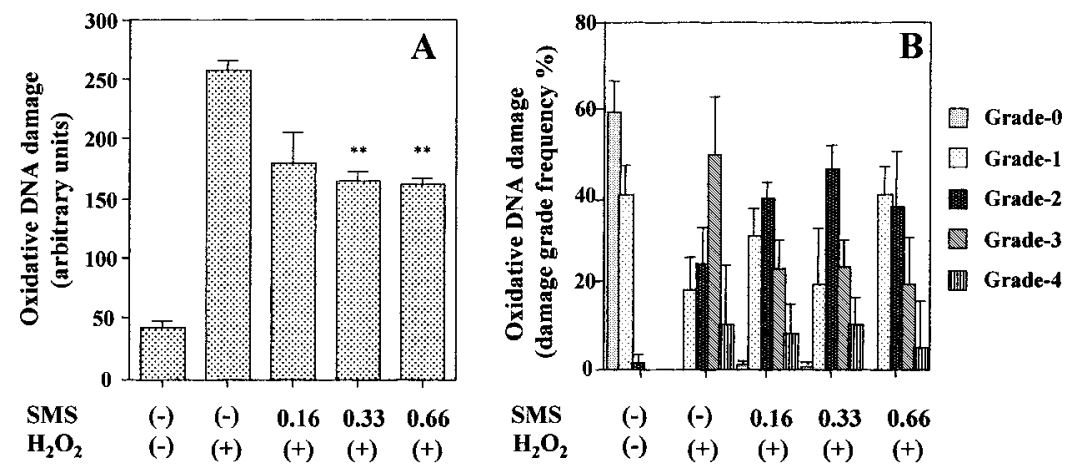

Fig. 3. Prevention of $\mathrm{H}_{2} \mathrm{O}_{2}$-Induced DNA Damage in PC12 Cells by SMS

$\mathrm{PC} 12$ cells $\left(5 \times 10^{4} / \mathrm{cm}^{2}\right)$ were pre-incubated with various concentrations of SMS $(0.16-0.66 \mathrm{mg} / \mathrm{ml})$ for $24 \mathrm{~h}$ and then chased with $0.3 \mathrm{~mm} \mathrm{H}_{2} \mathrm{O}_{2}$ for $30 \mathrm{~min}$ at $37{ }^{\circ} \mathrm{C}$. DNA damage (SSBs) was determined by a Comet assay. Data represent the means \pm S.D. of 3 independent experiments. $* * p<0.01$ compared to the $\mathrm{H}_{2} \mathrm{O}_{2}$ control. (A) overall damage, $(\mathrm{B})$ damage grade profile.
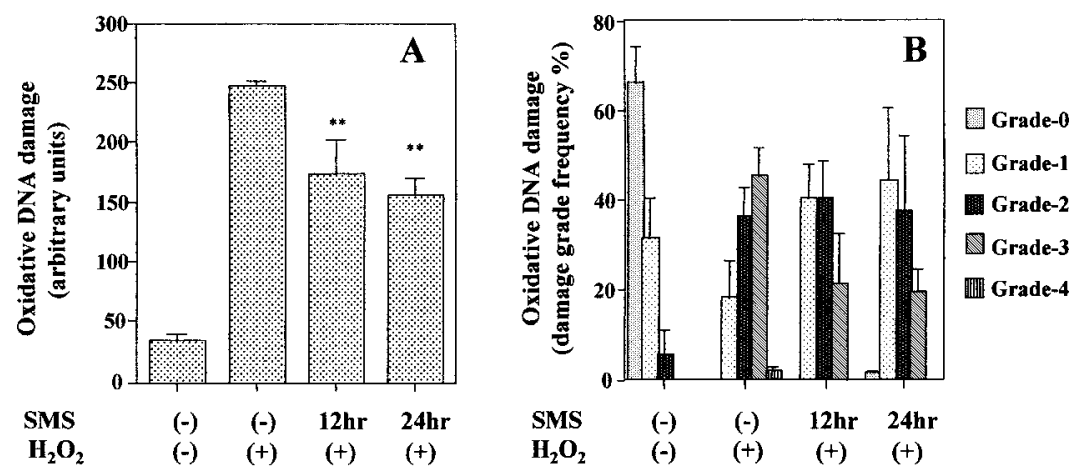

Fig. 4. Effect of the Pre-incubation Period on DNA Damage Protection by SMS

$\mathrm{PC} 12$ cells $\left(5 \times 10^{4} / \mathrm{cm}^{2}\right)$ were pre-incubated with $0.66 \mathrm{mg} / \mathrm{ml}$ of SMS for $12 \mathrm{~h}$ and $24 \mathrm{~h}$, respectively, and then chased with $0.3 \mathrm{~mm} \mathrm{H}_{2} \mathrm{O}_{2}$ for $30 \mathrm{~min}$ at $37{ }^{\circ} \mathrm{C}$. Other conditions were as in Fig. 3. Data represent the means \pm S.D. of 3 independent experiments. $* * p<0.01$ compared to the $\mathrm{H}_{2} \mathrm{O}_{2}$ control. (A) overall damage, (B) damage grade profile. 


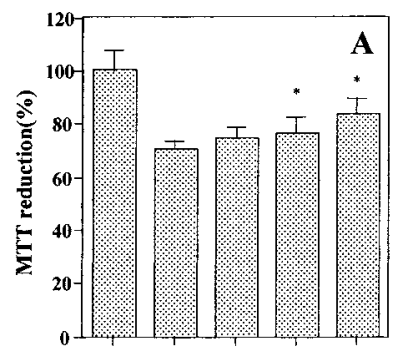

$\begin{array}{llllll}\text { SMS } & (-) & (-) & 0.16 & 0.33 & 0.66\end{array}$ $\begin{array}{llllll}\mathrm{H}_{2} \mathrm{O}_{2} & (-) & (+) & (+) & (+) & (+)\end{array}$

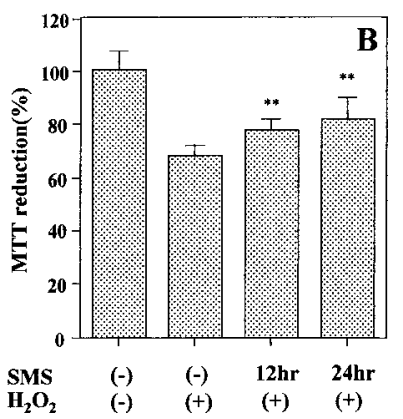

Fig. 5. Effect of SMS on the Viability of PC12 Cells after $\mathrm{H}_{2} \mathrm{O}_{2}$ Abuse

(A) Cells $\left(1 \times 10^{4} / \mathrm{cm}^{2}\right)$ were pre-incubated with various concentrations of SMS $(0.16-0.66 \mathrm{mg} / \mathrm{ml})$ for $24 \mathrm{~h}$ and then chased with $0.5 \mathrm{~mm} \mathrm{H}_{2} \mathrm{O}_{2}$ for $30 \mathrm{~min}$ at $37^{\circ} \mathrm{C}$. (B) Cells were pre-treated with $0.66 \mathrm{mg} / \mathrm{ml}$ of SMS for 12 and $24 \mathrm{~h}$, respectively, and then chased with $0.5 \mathrm{mM} \mathrm{H}_{2} \mathrm{O}_{2}$ for $30 \mathrm{~min}$. Cell viability was determined by the MTT reduction method. Data represent the means \pm S.D. of 6 cell cultures. $* p<0.05, * * p<0.01$ compared to the $\mathrm{H}_{2} \mathrm{O}_{2}$ control.

on the antioxidant TCM formula as a model for antioxidantbased composite therapy against the brain disorders associated with oxidative stress, and revealed that SMS effectively prevented oxidative injury in terms of lipid peroxidation and glutathione peroxidase (GPX) activity changes ${ }^{10,11)}$ after cerebral ischemia reperfusion in rats. Taking other reports into consideration that the constituent herbs of SMS and their ingredients, especially ginsenosides from ginseng, have neuroprotective activities, such as promotion of hippocampal neuronal function, ${ }^{21)}$ and prevention of cortical neurons and cultured PC12 cells undergoing apoptosis, ${ }^{22,23)}$ we expected that SMS might also be useful for treating brain disorders. Indeed, SMS has been examined for slowing or preventing aging and Alzheimer's disease elsewhere. ${ }^{24)}$

In TCM, multi-component prescriptions are usually used for treating diseases. Therefore, complex modes of interactions among the component herbs are involved in their actions, such as additive, synergistic, restraint and antagonistic interactions. These interactions are, however, considered to be essential for improving their therapeutic potential, and also for reducing the side effects from certain toxic ingredients. $^{25)}$ Currently, these characteristics of TCM attract attention as alternative medicines for the treatment of complex diseases when Western medicines are rendered ineffective. It is thus useful to evaluate the effects of SMS in the cultured cell system as well as in vivo for further understanding of its protective mechanism against cerebral oxidative injury.

In the present study, the protective effects of SMS against $\mathrm{H}_{2} \mathrm{O}_{2}$-induced oxidative insults were examined in PC12 cells as a neuronal cell model. $\mathrm{H}_{2} \mathrm{O}_{2}$ is one of the major reactive oxygen species associated with oxidative stress. It readily penetrates into cells and reacts with intracellular metal ions, such as iron or copper, to generate highly reactive hydroxyl radicals that successively attack cellular components including lipids, proteins and DNA to cause a wide variety of oxidative insults. ${ }^{26,27)}$ Oxidative damage of amino acid residues in proteins results in the formation of carbonyl derivatives. ${ }^{28)}$ Therefore, protein carbonyl formation serves as a biomarker of cellular oxidative damage. ${ }^{29)}$ On the other hand, oxidative damage of DNA involves both base lesions and SSBs. This DNA damage eventually leads to genetic mutations. ${ }^{30)}$ Indeed, considerable amounts of protein and DNA damage were produced in $\mathrm{PC} 12$ cells after $\mathrm{H}_{2} \mathrm{O}_{2}$ abuse in the present study, and it was revealed that SMS pretreatment prior to the $\mathrm{H}_{2} \mathrm{O}_{2}$ chase significantly reduced both protein and DNA damage, and consequently protected the cells from death in a dose-dependent manner. For clinical treatment, approximately $6 \mathrm{~g}$ of SMS as dry herbs is taken twice a day. Therefore, the SMS concentration used in the present experiments (between 0.16 to $0.66 \mathrm{mg}$ original dry herbs $/ \mathrm{ml}$ ) is almost comparable to the SMS concentration in the blood plasma estimated from the assumptions that SMS is distributed equally in a body weighing $50 \mathrm{~kg}$ and that the body water mass is $70 \%$ of the body weight.

It is suggested that the protection of cells against the $\mathrm{H}_{2} \mathrm{O}_{2}$ abuse by SMS is not due to its direct reaction with $\mathrm{H}_{2} \mathrm{O}_{2}$, because extracellular SMS was washed out before the $\mathrm{H}_{2} \mathrm{O}_{2}$ was added to the culture medium in the present experiments. It is more likely that the protective effect is due to its high scavenging potential against hydroxyl radicals since the strong hydroxyl radical scavenging activity of SMS has previously been demonstrated in vitro. ${ }^{12)}$ However, it is important to note that the protective activity of SMS against the $\mathrm{H}_{2} \mathrm{O}_{2}$ abuse was enhanced after the cells were incubated with SMS for the longer period $(24 \mathrm{~h})$ compared with the shorter period $(12 \mathrm{~h})$. Explanations for this are either that it took time to accumulate sufficient antioxidant ingredients of SMS into the cells to prevent the $\mathrm{H}_{2} \mathrm{O}_{2}$-mediated oxidative injury or that secondary transformation of the SMS ingredients in the cells was necessary to achieve the antioxidant protection. However, the secondary transformation is less likely because SMS itself has high potential as a radical scavenger. ${ }^{12)}$ Modulation of cellular antioxidant systems by SMS might be another, and more probable, mechanism of the enhanced antioxidant potential of PC12 cells, as was suggested in our previous finding that SMS prevented the loss of GPX activity in the brain after ischemia reperfusion in rats. ${ }^{11,12)}$ This is also supported by our recent observation that SMS enhanced the expression of GPX activity in cultured myoblasts at both the transcriptional and post-transcriptional levels (paper in preparation). Similar modulation effects of SMS on antioxidant defense enzymes were reported elsewhere, such as that hepatic glutathione (GSH) contents were increased in SMSadministered rats following $\mathrm{CCl}_{4}$ intoxication ${ }^{31)}$ and that Panax ginseng, one of the component herbs of SMS, enhanced SOD activity $^{32)}$ and also activated the $\mathrm{Cu}, \mathrm{Zn}-\mathrm{SOD}$ gene at the transcriptional level. ${ }^{33)}$ It is thus concluded that SMS taken up into cells modulates the cellular antioxidant potential either by acting as an antioxidant or free radical scavenger by itself or by activating intracellular antioxidants and damage repair enzymes. Further investigations are underway to clarify the precise mechanism of the SMS effects and also the active ingredients functioning in the modulation of cellular antioxidant defenses or other multiple pathways leading to cell death.

Acknowledgements This study was supported in part by a grant from the Promotion and Mutual Aid Corporation for Private Schools in Japan. We also thank Iskura Co. Ltd. for providing the Shengmai San preparation (Bakumi-San granules). 


\section{REFERENCES}

1) Hinshaw D. B, Miller M. T., Omann G. M., Beals T. F., Hyslop P. A., Brain Res., 615, 13-26 (1993).

2) Bowling A. C., Beal M. F., Life Sci., 56, 1151-1171 (1995).

3) Adams J. D. Jr., Odunze I. N., Free Radic. Biol. Med., 10, 161-169 (1991).

4) Markesbery W. R., Free Radic. Biol. Med., 23, 134-147 (1997).

5) Anderson D., Yu T.-W., Philips B. J., Schmezer P., Mutat. Res., 307, 261-271 (1994).

6) Tian L.-Q., Cai Q.-Y., Wei H. C., Free Radic. Biol. Med., 24, 14771484 (1998)

7) Duthie S. J., Ross M. A., Collins A. R, Cancer Res., 56, 1291-1295 (1996).

8) Gassen M., Gross A., Youdim M. B. H., Mov. Disord., 13, 661-667 (1998).

9) Joseph J. A., Strain J. G., Jimenez N. D., Fisher D., J. Neurochem., 69, $1252-1258$ (1997).

10) Wang H., Joseph J. A., Free Radic. Biol. Med., 27, 683 -694 (1999).

11) Wang X.-J., Magara T., Konishi T., Free Rad. Res., 31, 449—455 (1999).

12) Ichikawa H., Konishi T., Biol. Pharm. Bull., 25, 898-903 (2002).

13) Li P.-C., Poon M. K. T., Ko K. M., Am. J. Chin. Med., 24, 255-262 (1996)

14) Wang N.-Y., Minatoguchi S., Arai M., Uno Y., Nishida Y., Hashimoto K., Chen X. H., Fukuda K., Akao S., Takemura G., Fujiwara H., Circ. $J ., 66,763-768$ (2002).

15) Buss H., Chan T. P., Sluis K. B., Domigan N. M., Winterbourn C. C., Free Radic. Biol. Med., 23, 361-366 (1997).
16) Reznick A. Z., Packer L., Methods Enzymol., 233, 357-363 (1994)

17) Smith P. K., Krohn R. I., Hermanson G. T., Kallia A. K., Gartner F. H., Provenzano M. D., Fujimoto E. K., Goeke N. M., Olson B. J., Klenk D. C., Anal. Biochem., 150, 76-85 (1985).

18) Singh N. P., McCoy M. T., Tice R. R., Schneider E. L., Exp. Cell Res., 175, 184-191 (1988).

19) Chen X., Nishida H., Konishi T., Biol. Pharm. Bull., 26, 282-284 (2003).

20) Hansen M. B., Nielsen S. E., Berg K., J. Immunol. Methods, 119, 203-210 (1989).

21) Yu S.-C., Li X.-Y., Acta Pharmacol. Sin., 21, 915-918 (2000).

22) Li J.-Q., Zhang X.-G., Zhang J.-T., Acta Pharm. Sin., 32, 406-410 (1997).

23) Chen X.-C., Zhu Y.-G., Wang X.-Z., Zhu L.-A., Huang C., Acta Pharmacol. Sin., 22, 673-678 (2001).

24) Qiu B. X., Zhong Yao Yao Li Yu Ling Chuang, 9, 2-6 (1993).

25) Cheng J.-T., J. Clin. Pharmacol., 40, 445-450 (2000).

26) Denisova N. A., Cantuti-Castelvetri I., Hassan W. N., Paulson K. E., Joseph J. A., Free Radic. Biol. Med., 30, 671-678 (2001).

27) Halliwell B., Aruoma O. I., FEBS Lett., 281, 9-19 (1991).

28) Stadtman E. R., Berlett B. S., Drug Metab. Rev., 30, 225-243 (1998).

29) Stadtman E. R., Annu. Rev. Biochem., 62, 797-821 (1993).

30) Sankaranarayanan K., Mutat. Res., 258, 75-97 (1991).

31) Ko K. M., Yick P. K., Poon M. K. T., Che C.-T., Ng K. H., Kong Y.-C., Phytotherapy Res., 9, 203 -206 (1995).

32) Chu G.-X., Chen X., Acta Pharmacol. Sin., 11, 119-123 (1990).

33) Kim Y.-H., Park K. H., Rho H. M., J. Biol. Chem., 271, 24539-24543 (1996). 